\title{
Culicoides baniwa sp.nov. from the Brazilian Amazon Region with a synopsis of the hylas species group (Diptera: Ceratopogonidae)
}

\author{
Maria Luiza Felippe-Bauer ${ }^{1 /+}$, Camila Pinto Damasceno², Victor Py-Daniel ${ }^{2}$, Gustavo R Spinelli ${ }^{3}$ \\ 'Laboratório de Diptera, Instituto Oswaldo Cruz-Fiocruz, Av. Brasil 4365, 21040-900 Rio de Janeiro, RJ, Brasil ²Laboratório \\ de Etnoepidemiologia, Instituto Nacional de Pesquisas da Amazônia, Manaus, AM, Brasil División de Entomología, \\ Museo de La Plata, La Plata, Argentina
}

A new species of the Culicoides (Hoffmania) hylas species group, Culicoides baniwa Felippe-Bauer is described and illustrated based on a female specimen from the state of Amazonas, Brazil. A systematic key, wing photographs, diagramme of the legs pattern, table with numerical characters of females and a synopsis of the 11 species of the C. hylas group are presented. This paper further presents a new record of Culicoides pseudoheliconiae Felippe-Bauer out of the previously defined geographic distribution of the hylas species group, in the province of Misiones, Argentina.

Key words: Amazon - Brazil - Culicoides baniwa sp.nov. - Culicoides hylas group - neotropical bloodsucking midges - new record

Wirth and Blanton (1956) re-described and keyed out the three species of the subgenus Hoffmania Fox of $\mathrm{Cu}$ licoides Latreille previously related to Culicoides hylas Macfie and first recognized the hylas species group. In their 1956 paper, they treated Culicoides contubernalis Ortíz \& León as a variety of Culicoides rozeboomi Barbosa and considered it to be a junior synonym of $\mathrm{Cu}$ licoides verecundus Macfie. Wirth and Blanton (1968) reviewed the species group, describing three more species and establishing that they occur between Veracruz in Mexico through Central and South America to Ecuador and the Amazon Region of Brazil, Colombia and Peru. Recently, Felippe-Bauer et al. (2008) described Culicoides pseudoheliconiae Felippe-Bauer from Peruvian Amazon and re-established C. contubernalis as an autonomous species. Finally, Spinelli et al. (2009) described Culicoides antioquiensis Spinelli from Colombia. Currently, the hylas species group is known to contain 10 species, half of which (Culicoides aitkeni Wirth \& Blanton, Culicoides heliconiae Fox \& Hoffmann, Culicoides hylas Macfie, Culicoides palpalis Macfie, Culicoides polypori Wirth \& Blanton and C. verecundus Macfie) inhabit the Brazilian Amazon Region.

In the present paper, we describe and illustrate a new species from the Amazon Basin of Brazil and provide a key, a table of numerical characters, a diagramme of the leg pattern of female specimens and a synopsis of the 11 species actually belonging to the hylas species group. We also report the presence of $C$. pseudoheliconiae Felippe-Bauer in the Misiones province in Argentina,

Financial support: CAPES (CPD), FAPEAM (0348), FINEP (0852) + Corresponding author: mlfbauer@ioc.fiocruz.br

Received 28 January 2009

Accepted 16 July 2009 a subtropical forest area situated south of the Amazon Region. This report represents an extension of the previously described southern limit of the geographic distribution of the hylas species group.

\section{MATERIAL AND METHODS}

The specimen described herein as a new species was collected while it was biting a human during an entomological survey in São Gabriel da Cachoeira, Amazonas (AM), Brazil. The specimen was mounted in phenolbalsam in the manner described by Wirth and Marston (1968) and has been deposited in the Invertebrate Collection of the Instituto Nacional de Pesquisas da Amazônia (INPA), AM, Brazil. Specimens of the other studied species were deposited in the Ceratopogonidae Collection of the Instituto Oswaldo Cruz and in the Collection of the Museo de La Plata (MLP), Argentina. Diagnostic characters were illustrated using a camera lucida attached to an Olympus BH-2 microscope. Microphotographies of the wings were taken with a Nikon Eclipse E-800; brightness and contrast of images were adjusted using Adobe Photoshop CS2.

In this paper, we follow the terminology established in Culicoides papers by Spinelli et al. (2005) and FelippeBauer et al. (2008). Therms of wing veins follow the system of the Manual of Neartic Diptera (MacAlpine et al. 1981) with modifications proposed by Szadziewski (1996). All measurements are in micrometres, except those of the wings which are in millimetres.

\section{Culicoides hylas group}

Diagnosis: medium to large sized species belonging to subgenus Hoffmania Fox with dark brown to blackish colour and wings with very distinct pale spots. Wing (Figs 1-10, 17) with second radial cell included in a single or subdivided pale spot; base of cell cua dark where it borders the bases of veins $\mathrm{CuA}_{1}$ and $\mathrm{CuA}_{2}$; cell $\mathrm{r}_{3}$ shows a pale spot usually present anterior to base of vein $M_{1}$; apices of veins $M_{1}$ and $M_{2}$ pale; apices of veins $\mathrm{CuA}_{1}$ and $\mathrm{CuA}_{2}$ with or without pale spot, depending on the species. Mesonotum dark brown to black with a prominent 
pattern of large pale or pruinose areas. Eyes contiguous, bare. Antenna long and slender, segments with bases conspicuously pale; proximal flagellomeres not greatly shorted, sensilla coeloconica present on flagellomeres 1 , 9-13. Palpus slender; third palpal segment slender, cylindrical to spindleshaped, usually with scattered sensilla, palpal ratio varies between 2.7-6.0. Legs dark brown with distinct pale bands characteristic of each species; hind tibial comb shows six spines, the longest of which is the second from the spur. Two spermathecae usually with short, slender necks plus a rudimentary third and sclerotized ring. Male tergite 9 rounded posteriorly, without conspicuous apicolateral processes; posteromedial margin with distinctive lobe or processes; sternite 9 with shallow posteromedial excavation, the ventral membrane not spiculate. Gonocoxite slender, dorsal and ventral root not developed; gonostylus curved and slender with moderately sharp pointed tip. Aedeagus narrow with very short basal arch, the anterior margin with distinct sclerotized band; distal portion with internal sclerotized projection, ending in a rounded papilla. Parameres fused at base usually for about half of total length, separate portion abruptly tapered to slender terminal filaments with very fine distal fringing hairs.

\section{Key to the species of the Culicoides hylas group}

1. Hind femur dark to tip (Figs 13-16) ................... 2 - Hind femur with subapical pale band (Figs 11, 12) ... 7

2. Mid femur dark to tip (Fig. 16), a double distal pale spot in $\mathrm{r}_{3}$ pale spot absent in front of base of M1 (Fig. 17) baniwa Felippe-Bauer sp.nov.

- Mid femur various, a single distal pale spot in $r_{3}$ pale spot present in front of base of vein M1 ............... $3^{3}$

3. Mid femur with subapical pale band (mid knee dark; Fig. 15); 3rd palpal segment with irregular sensory pit .............................................. hylas Macfie

- Mid femur with apical pale band (mid knee pale; Figs 13, 14); 3rd palpal segment without sensory pit, with scattered sensilla on surface of 3rd segment 4

4. Wing markings diffuse, dark and pale spots not brightly contrasting; pale spot that crosses second radial cell subdivided in two separate spots (Fig. 8) pseudoheliconiae Felippe-Bauer

- Wing with contrasting pattern of dark and pale spots; pale spot that crosses the second radial cell, single ....... 5

5. Distal pale spot in $\mathrm{r}_{3}$ narrow and transverse; apices of $\mathrm{CuA}_{1}$ and $\mathrm{CuA}_{2}$ pale (Fig. 4) ....

heliconiae Fox \& Hoffman

- Distal pale spot in cell $\mathrm{r}_{3}$ large; apices of $\mathrm{CuA}_{1}$ and $\mathrm{CuA}_{2}$ various ... 6

6. Apices of $\mathrm{CuA}_{1}$ and $\mathrm{CuA}_{2}$ dark (Fig. 6) palpalis Macfie

- Apices of $\mathrm{CuA}_{1}$ pale and $\mathrm{CuA}_{2}$ dark (Fig. 2) antioquiensis Spinelli

7. Pale spot absent in front of base of M1 (Fig. 10); flagellomeres 2-8 with prominent four or five-branched hyaline sensory filaments....... xanifer Wirth \& Blanton

- Pale spot present in front of base of M1, flagellom- eres 2-8 with simple hyaline sensory filament ............ 8

8. Apices of $\mathrm{CuA}_{1}$ and $\mathrm{CuA}_{2}$ pale (Figs 1,3) ........ 9

- Apices of $\mathrm{CuA}_{1}$ and $\mathrm{CuA}_{2}$ dark (Figs 7, 9) ......... 10

9. Large species, wing length $1.50 \mathrm{~mm}$, P.R. 6.0, A.R. 1.26, $\mathrm{P} / \mathrm{H}$ ratio 1.38 ................ aitkeni Wirth \& Blanton

- Smaller species, wing length $1.30-1.35 \mathrm{~mm}$, P.R. 3.8-4.3, A.R. 1.09-1.14, $\mathrm{P} / \mathrm{H}$ ratio 1.14-1.18 contubernalis Ortiz \& Leon

10. Mid femur with subapical pale band (Fig. 11) ..... . polypori Wirth \& Blanton

- Mid femur with apical pale band (Fig. 12) verecundus Macfie

\section{C. aitkeni Wirth \& Blanton \\ (Figs 1, 11)}

C. aitkeni Wirth \& Blanton, 1968: 214 (female, Trinidad and Tobago; Figs; in key), Wirth \& Blanton, 1973: 424 (Amazon records, Brazil), Aitken et al., 1975: 115 (Trinidad and Tobago records, wing photo), Wirth et al., 1988: 19 (in Atlas; wing photo; distribution), Borkent \& Wirth, 1997: 61 (in catalogue), Borkent \& Spinelli, 2000: 33 (in catalogue), Borkent \& Spinelli, 2007: 67 (in catalogue), Felippe-Bauer et al., 2008: 260 (in key).

Diagnosis: the female of the species possesses the following combination of characters: third palpal segment with scattered sensilla; wing length $1.50 \mathrm{~mm}, \mathrm{r}_{3}$ with pale spot present anterior to base of $\mathrm{M}_{1}$ and in apices of $\mathrm{CuA}_{1}$ and $\mathrm{CuA}_{2}$, a single pale spot crossing second radial cell; mid and hind femur with subapical pale band; spermathecae with short, slender necks.

Male: unknown.

Distribution - Trinidad and Tobago, Brazil [Pará (PA)].

\section{C. antioquiensis Spinelli}

(Figs 2, 13)

C. antioquiensis Spinelli (in Spinelli et al. 2009): 82 (male, female; Colombia)

Diagnosis: the species possesses the following combination of characters: third palpal segment with scattered sensilla; mid femur with apical pale band, hind femur dark to tip; wing with apices of $\mathrm{CuA}_{1}$ pale and apex of $\mathrm{CuA}_{2}$ dark, $\mathrm{r}_{3}$ with pale spot present anterior to base of $\mathrm{M}_{1}$, a single pale spot crosses the second radial cell and wing pattern most similar to $C$. hylas; spermathecae without sclerotized necks. Male tergite 9 somewhat truncated; gonostylus with subapical tooth; fused portion of the parameres 1.5 broader than long, separate portion V-shaped at base.

Distribution - Colombia.

\section{C. baniwa Felippe-Bauer, sp.nov.}

(Figs 16-22)

Diagnosis: this species is easily distinguished from the other species of the hylas group by the presence of double pale spots in $\mathrm{r}_{3}$, one crossing second radial cell and the other in distal portion of $r_{3}$, by the absence of pale spot in front of base of M1 and by the mid femur dark to tip. 

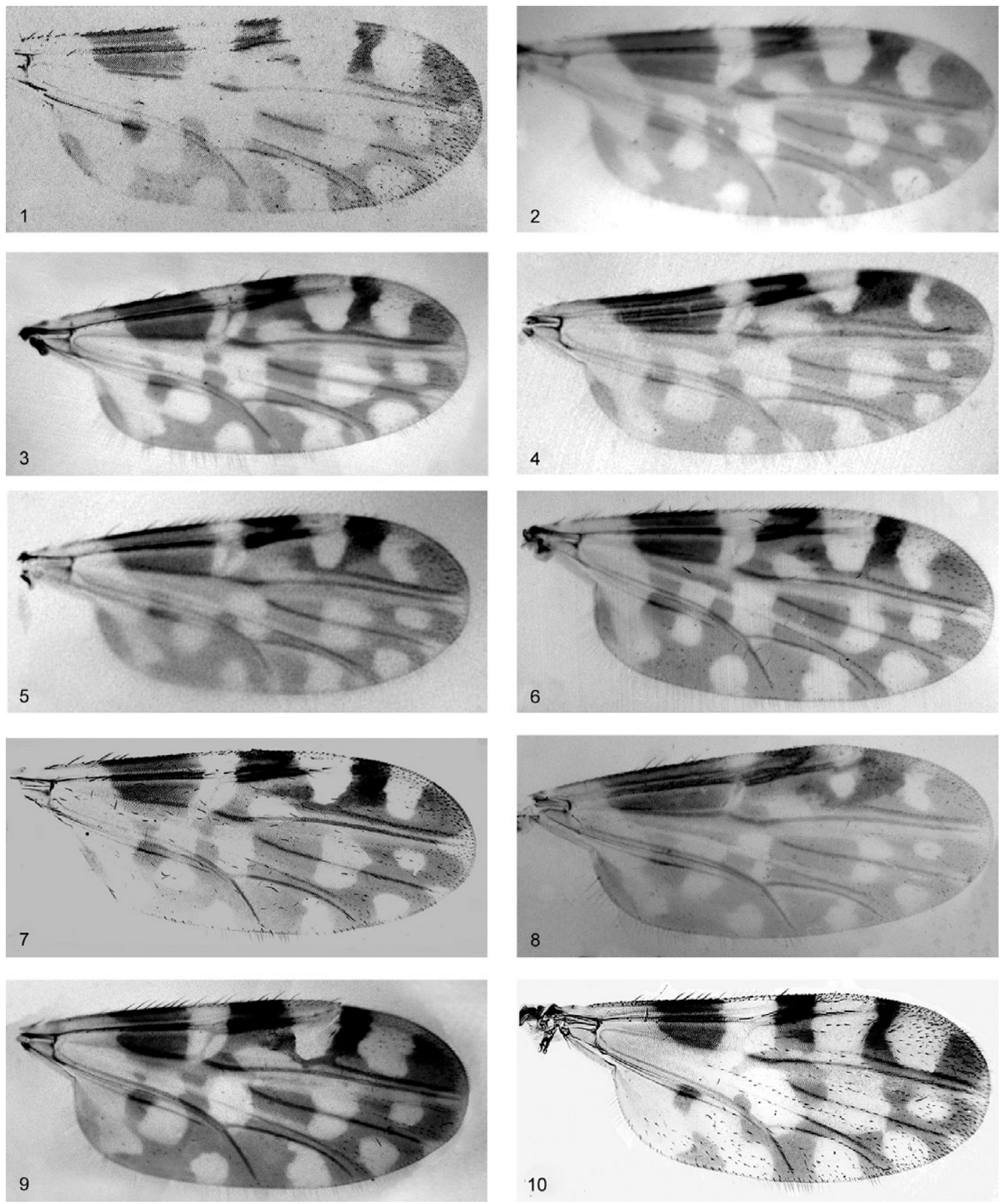

Figs 1-10: wing photograph of Culicoides hylas species group. 1: Culicoides aitkeni; 2: Culicoides antioquiensis; 3: Culicoides contubernalis; 4: Culicoides heliconiae; 5: Culicoides hylas; 6: Culicoides palpalis; 7: Culicoides polypori; 8: Culicoides pseudoheliconiae; 9: Culicoides verecundus; 10: Culicoides xanifer.

Male: unknown.

Female: wing length $1.32 \mathrm{~mm}$; breadth $0.54 \mathrm{~mm}$.

Head: dark brown. Eyes contiguous, bare. Pedicel dark brown. Flagellum (Fig. 18) brown, with base of flagellomeres conspicuously pale; flagelomeres with mean lengths of 75-107-107-107-107-107-107-107-75-8085-91-139 $\mu \mathrm{m}$; antennal ratio 1.05; sensilla coeloconia on flagellomeres 1, 9-13, three on 1, one on 9-13. Palpus (Fig. 21) brown, apices of the segments 1-4 pale, base of the third segment pale, fifth segment entirely pale; lengths of segments 27-128-149-53-53 $\mu \mathrm{m}$; third segment slender, subcylindrical, without sensory pit, with scattered sensilla on surface; palpal ratio 4.7. Proboscis brown, $\mathrm{P} / \mathrm{H}$ ratio 1.48; mandible with 27 teeth.

Thorax: dark brown; scutum, scutellum, postscutellum, pleuron dark brown. Legs mostly dark brown; fore femur with apical pale band, mid and hind femur entirely dark; mid knee dark; tibiae with subbasal pale bands; hind tibia pale apically (Figs 16, 22); hind tibial comb with six spines, the second from de spur longest (Fig. 20). Tarsi pale, first 


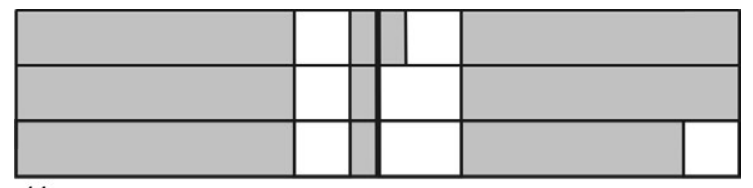

11

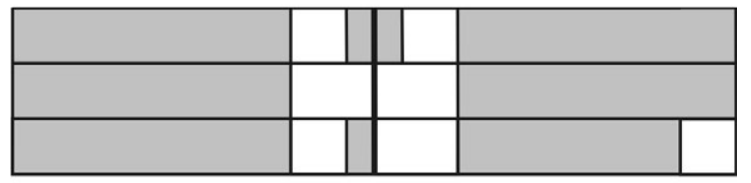

12

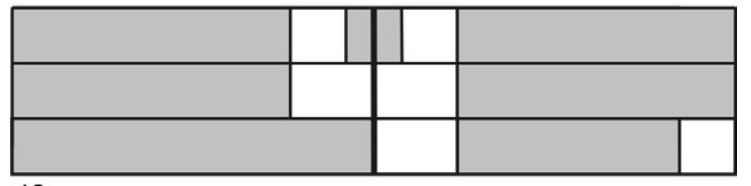

13

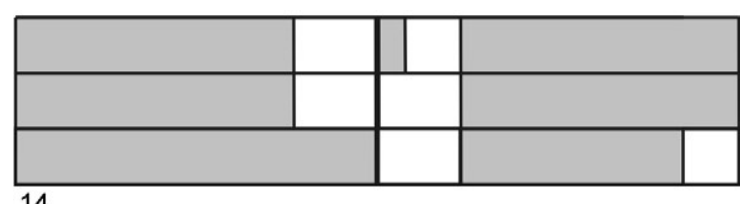

14
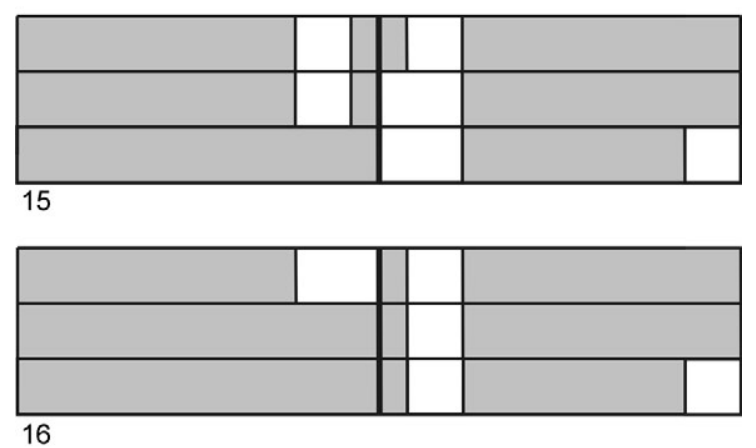

Figs 11-16: leg pattern of Culicoides hylas species group (top to bottom: fore, mid and hind; left to right: femur and tibia). 11: Culicoides aitkeni, Culicoides contubernalis and Culicoides polypori; 12: Culicoides verecundus and Culicoides xanifer; 13: Culicoides antioquiensis, Culicoides heliconiae and Culicoides palpalis; 14: Culicoides pseudoheliconiae; 15: Culicoides hylas; 16: Culicoides baniwa sp.nov.

tarsomeres darkest. Wing (Fig. 17) with pattern typical of hylas group: one round pale spot over the second radial cell; two spots on $\mathrm{r}_{3}$ : one just below the pale spot on second radial cell not reaching $\mathrm{M} 1$, the other a distal, double pale spot; pale spot over r-m crossvein extending from $\mathrm{M}$ to costal margin, narrow, slender; $\mathrm{m}_{1}$ with two rounded pale spots, distal spot smaller and farther from wing margin; $\mathrm{m}_{2}$ shows one proximal pale spot, double pale spot lying between medial, mediocubital forks, one subapical, another in distal portion near wing margin; cua ${ }_{1}$ with rounded pale spot extending from $\mathrm{CuA}_{1}$ to wing margin; anal cell with two well separated pale spots on distal portion, one anterior of mediocubital fork, the other near wing margin; base of the wing extensively pale since the costal vein to anal cell; apices of $\mathrm{M}_{1}, \mathrm{M}_{2}, \mathrm{CuA}_{1}, \mathrm{CuA}_{2}$ pale; costal ratio 0.69 . Halter pale, base of the knob infuscate.
Abdomen: brown. Two unequal sized ovoid spermathecae (Fig. 19) without necks, measuring 48 by 37 $\mu \mathrm{m}$ and 37 by $32 \mu \mathrm{m}$, respectively. Rudimentary third spermathecae, short sclerotized ring present.

\section{Distribution - Brazil (AM).}

Type data and depository - Holotype female, Comunidade de Assunção, Rio Içana, São Gabriel da Cachoeira $\left(01^{\circ} 03^{\prime} 44,5^{\prime}\right.$ 'N 67³5'36,0”'W), AM, Brazil, 25.XI.2007, biting human, 6-6:30 h, Damasceno col. Deposited in Invertebrates Collection of INPA (INPA/LETEP 6301), AM, Brazil.

Etymology - This species is named in honour of the Baniwa Indians who live in location where the specimen was found.

Taxonomic discussion - C. baniwa sp.nov. is a typical member of the subgenus Hoffmania and, as outlined in the key and in the Table, may be distinguished from other species of the hylas group by the double distal pale spot in $r_{3}$, the absence of the pale spot in front of base of $M_{1}$ the long proboscis and by the entirely dark mid femur and pale fifth palpal segment.

\section{C. contubernalis Ortiz \& Leon}

(Figs 3, 11)

C. contubernalis Ortiz\& Leon, 1954:574(female; Ecuador; Figs antennae, palpus, spermathecae, wing; as var. of rozeboomi), Felippe-Bauer et al., 2008: 261 (revalid., redescript., Figs); C. verecundus Wirth \& Blanton, 1956: 98 (C. contubernalis var. of rozeboomi as syn.), Forattini, 1957: 249 (in neotropical catalogue; in part, Ecuador records), Wirth \& Blanton, 1959: 278 (in part, Ecuador records), Wirth \& Blanton, 1968: 209 (in part, Ecuador records), Wirth et al., 1988: 20 (in Atlas; in part, Ecuador records), Borkent \& Wirth, 1997: 85 (in catalogue; C. contubernalis var. of rozeboomi as syn.), Borkent \& Spinelli, 2000: 35 (in catalogue, C. contubernalis var. of rozeboomi as syn.), Borkent \& Spinelli, 2007: 69 (in catalogue, C. contubernalis var. of rozeboomi as syn.).

Diagnosis: species distinguished from other species of the hylas group by its medium size, mid and hind femur with subapical pale band; pale spot present anterior to base of $\mathrm{M}_{1}$ on $\mathrm{r}_{3}$, a single pale spot crosses the second radial cell, apices of $\mathrm{CuA}_{1}$ and $\mathrm{CuA}_{2}$ pale. The wing pattern is most similar to verecundus; P.R. 4.1, $\mathrm{P} / \mathrm{H}$ ratio 1.15 and A.R.1.11.

Male: unknown.

Distribution - Ecuador (Pichincha), Peru (Madre de Dios).

\section{C. heliconiae Fox \& Hoffman}

(Figs 4, 13)

C. heliconiae Fox \& Hoffman, 1944: 108 (male, female; Venezuela; wing photo; bionomic dates), Fox, 1948: 22 (male, female, Figs; Trinidad and Tobago, Hondura records; bionomic dates), Ortiz, 1950: 450 (discussion), Wirth \& Blanton, 1956: 95 (male, female, Figs; distribution, misident. in part, Peru record, syn. palpalis; rozeboomi as syn.), Wirth \& Blanton, 1959: 274 (redescript.; Figs), Williams, 1964: 463 (bionomic dates), 
TABLE

Numerical characters of females of the Culicoides hylas Group

\begin{tabular}{lccccc}
\hline Species $^{a}$ & $\begin{array}{c}\text { Wing length } \\
(\mathrm{mm})\end{array}$ & $\begin{array}{c}\text { Costal } \\
\text { ratio }\end{array}$ & $\begin{array}{c}\text { Antennal } \\
\text { ratio }\end{array}$ & $\begin{array}{c}\text { Palpal } \\
\text { ratio }\end{array}$ & $\begin{array}{c}\text { P/H } \\
\text { ratio }\end{array}$ \\
\hline aitkeni & 1.50 & 0.70 & 1.26 & 6.0 & 1.38 \\
antioquiensis & 1.40 & 0.67 & 1.00 & 4.1 & 1.23 \\
baniwa sp.nov. & 1.32 & 0.69 & 1.05 & 4.7 & 1.48 \\
contubernalis & $1.30-1.35$ & $0.66-0.69$ & $1.09-1.14$ & $3.8-4.3$ & $1.14-1.18$ \\
heliconiae & $1.29-1.69$ & $0.66-0.75$ & $0.99-1.12$ & $3.1-4.6$ & 1.33 \\
hylas & $0.99-1.29$ & $0.67-0.72$ & $1.03-1.16$ & $2.7-4.0$ & 1.15 \\
palpalis & $1.38-1.59$ & $0.65-0.74$ & $1.07-1.20$ & $3.2-6.0$ & 1.32 \\
polypori & $1.25-1.59$ & $0.68-0.72$ & $1.09-1.28$ & $3.4-5.6$ & 1.20 \\
pseudonheliconiae & $1.22-1.27$ & $0.67-0.70$ & $1.01-1.03$ & $3.7-4.3$ & $1.08-1.09$ \\
verecundus & $1.35-1.56$ & $0.65-0.72$ & $1.01-1.09$ & $4.6-5.9$ & 1.40 \\
xanifer & $1.29-1.50$ & $0.66-0.72$ & $0.97-1.06$ & $4.0-6.0$ & 1.25 \\
\hline
\end{tabular}

$a$ : arranged alphabetically.

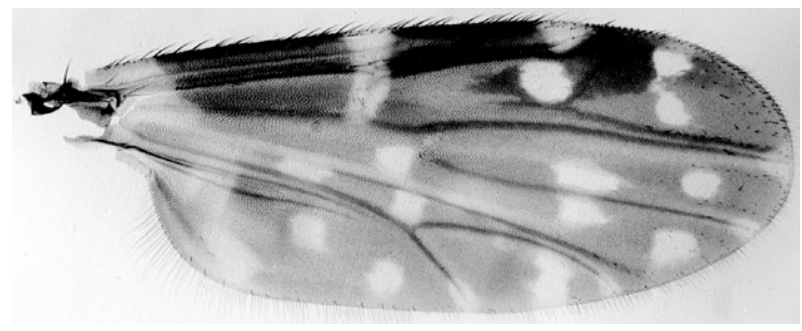

Fig. 17: wing photograph of Culicoides baniwa sp.nov., female.

Wirth \& Blanton, 1968: 205 (in key; redescript.; Figs), Wirth \& Blanton, 1973: 439 (Amazon records, Brazil, Colombia), Aitken et al., 1975: 129 (Trinidad and Tobago records, wing photo, distribution), Wirth et al., 1988: 18 (in Atlas; wing photo; distribution), Borkent \& Wirth, 1997: 70 (in catalogue), Borkent \& Spinelli, 2000: 34 (in catalogue), Borkent \& Spinelli, 2007: 68 (in catalogue), Felippe-Bauer et al., 2008: 260 (in key); C. rozeboomi Barbosa, 1947: 26 (male, female; Trinidad and Tobago; Figs); C. hylas Forattini, 1957: 244 (in part, heliconiae as syn.).

Diagnosis: species shows the following combination of characters: third palpal segment with scattered sensilla; apical pale band on mid femur, hind femur dark to tip; wing with distal pale spot in $r_{3}$ narrow and transverse, $r_{3}$ with pale spot present anterior to base of $M_{1}$, a single pale spot crosses the second radial cell, apices of $\mathrm{CuA}_{1}$ and $\mathrm{CuA}_{2}$ pale; spermathecae with short, slender necks. Male tergite 9 with posteromedial margin slightly pronounced, rounded, sometimes, slightly bilobed; fused portion of the parameres slightly broader than long, separate portion long and V-shaped at base.

Distribution - Belize to Ecuador, Venezuela, Brazil (AM, PA), Grenada, Trinidad and Tobago.

\section{C. hylas Macfie}

(Figs 5, 15)

C. hylas Macfie, 1940: 26 (female, Guyana; wing photo), Wirth \& Blanton, 1956: 98 (male, female; Figs; distribution), Forattini, 1957: 243 (in part; redescript.; Figs; distribution), Wirth \& Blanton, 1959: 276 (redescript.; Figs), Wirth \& Blanton, 1968: 203 (in key; redescript.; Figs; distribution), Wirth \& Blanton, 1973: 439 (Amazon records, Brazil, Colombia), Wirth et al., 1988: 18 (in Atlas; wing photo; distribution), Borkent \& Wirth, 1997: 70 (in catalogue), Borkent \& Spinelli, 2000: 34 (in catalogue), Borkent \& Spinelli, 2007: 68 (in catalogue), Felippe-Bauer et al., 2008: 260 (in key).

Diagnosis: the only species of the hylas group with an irregular sensory pit in the third palpal segment. Species also shows mid femur with subapical pale band, hind femur dark to tip; wing with $r_{3}$ with pale spot present anterior to base of vein $\mathrm{M}_{1}$, a single pale spot crossing the second radial cell, apices of $\mathrm{CuA}_{1}$ and $\mathrm{CuA}_{2}$ pale; spermathecae with short, slender necks. Male tergite 9 with small median papilliform process on posterior margin; fused portion of the parameres nearly as broad as long, separate portion slender, U-shaped at base.

\section{Distribution - Mexico to Peru, Brazil (PA).}

$$
\text { C. palpalis Macfie }
$$

(Figs 6, 13)

C. palpalis Macfie, 1948: 78 (female; Mexico), Wirth \& Blanton, 1968: 207 (in key; redescript.; Figs), Wirth \& Blanton, 1973: 443 (Amazon records, Colombia), Wirth et al., 1988: 20 (in Atlas; wing photo; distribution), Borkent \& Wirth, 1997: 77 (in catalogue), Borkent \& Spinelli, 2000: 34 (in catalogue), Borkent \& Spinel1i, 2007: 69 (in catalogue), Felippe-Bauer et al., 2008: 260 (in key); C. verecundus Ortiz \& Mirsa, 1952: 259 (male, female; Venezuela; Figs; palpalis as syn.), Wirth 


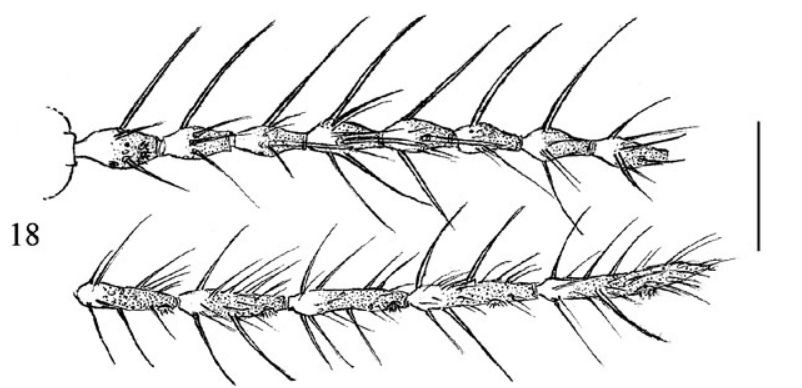

19
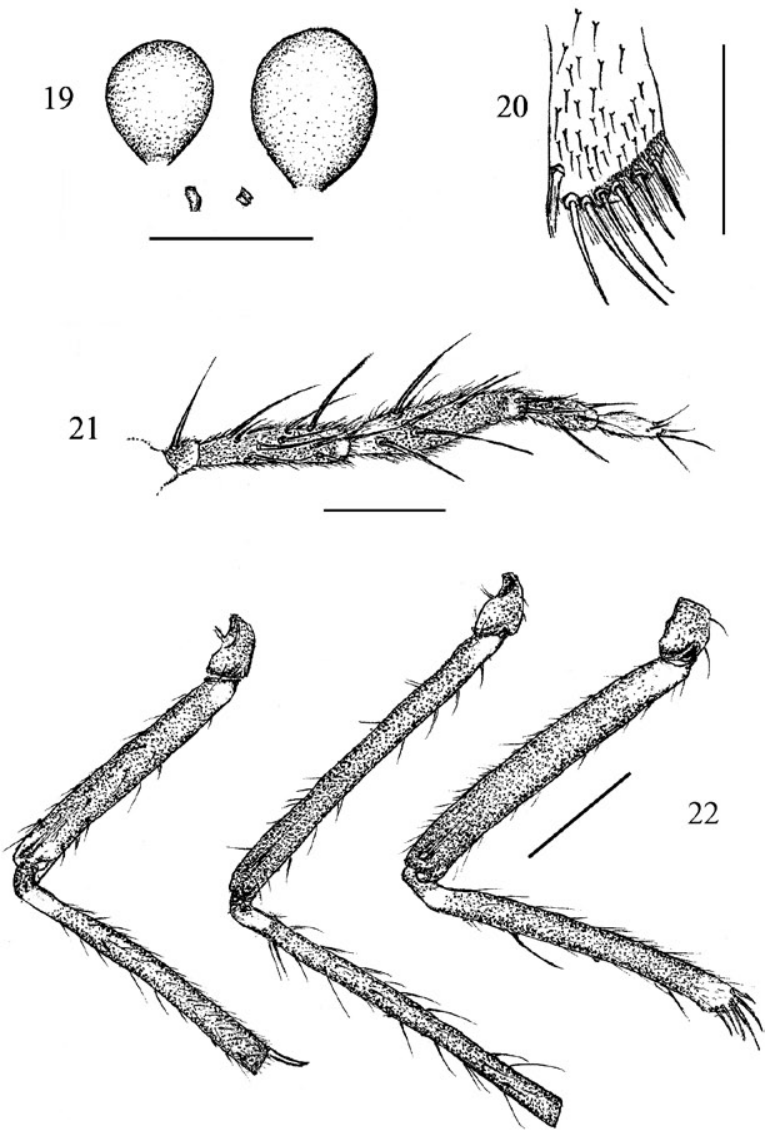

Figs 18-22: Culicoides baniwa sp.nov., female; 18: flagellum (scale bar: $0.1 \mathrm{~mm}$ ); 19: spermathecae (scale bar: $0.05 \mathrm{~mm}$ ); 20: hind tibial comb (scale bar: $0.1 \mathrm{~mm}$ ); 21: palpus (scale bar: $0.1 \mathrm{~mm}$ ); 22: legs (left to right) fore, mid and hind (scale bar: $0.2 \mathrm{~mm}$ ).

\& Blanton, 1956: 98 (palpalis as syn.), Forattini, 1957: 249 (in neotropical catalogue; palpalis as syn.), Wirth \& Blanton, 1959: (redescript., Figs; palpalis as syn.).

Diagnosis: the species shows the following combination of characters: third palpal segment with scattered sensilla; mid femur with apical pale band, hind femur dark to tip; $r_{3}$ shows a pale spot present anterior to base of $\mathrm{M}_{1}$, a single pale spot crosses the second radial cell, apices of $\mathrm{CuA}_{1}$ and $\mathrm{CuA}_{2}$ dark; spermathecae with short, slender necks. Male tergite 9 with very small papilliform process on posterior margin; fused portion of the parameres shows a width to length ratio of 1.75 .

Distribution - Mexico to Peru, Brazil (Amazon records).
C. polypori Wirth \& Blanton

(Figs 7, 11)

C. polypori Wirth \& Blanton, 1968: 212 (male, female; Panama), Wirth et al., 1988: 20 (in Atlas; wing photo; distribution), Borkent \& Wirth, 1997: 79 (in catalogue), Borkent \& Spinelli, 2000: 34 (in catalogue), Borkent \& Spinelli, 2007: 69 (in catalogue), FelippeBauer et al., 2008: 260 (in key); C. verecundus Wirth \& Blanton, 1956: 99 (misident., Panama specimens).

Diagnosis: species shows the following combination of characters: third palpal segment with scattered sensilla; mid and hind femur with subapical pale band; $r_{3}$ with pale spot present anterior to base of $\mathrm{M}_{1}$, a single pale spot crosses the second radial cell, apices of $\mathrm{CuA}_{1}$ and $\mathrm{CuA}_{2}$ dark; spermathecae with short, slender necks. Male tergite 9 with a bilobed process on posterior margin; fused portion of the parameres slightly longer than basal width.

Distribution - Honduras to Colombia, Brazil (AM).

\section{C. pseudoheliconiae Felippe-Bauer}

(Figs 8, 14)

C. pseudoheliconiae Felippe-Bauer (in Felippe-Bauer et al. 2008): 260 (female; Peru).

Diagnosis: this is the only species of the hylas group with pale wing markings that are diffuse, rather than brightly contrasting; $r_{3}$ with pale spot present anterior to base of $M_{1}$, pale spot that crosses the second radial cell subdivided in two separate spots, apices of $\mathrm{CuA}_{1}$ and $\mathrm{CuA}_{2}$ dark; third palpal segment with scattered sensilla; mid femur with apical pale band, hind femur dark to tip; spermathecae with short, slender necks.

Male: unknown.

Distribution - Peru (Madre de Dios, San Martin), Argentina (Misiones province).

New record - Ten females, Arroyo Mbocay, Puero Iguazú, Misiones, Argentina, 24.VIII.2008, CDC light trap, H. Walantus col. Deposited in the MLP, Argentina.

\section{C. verecundus Macfie}

(Figs 9, 12)

C. verecundus Macfie, 1948: 76 (male, female; Mexico; wing photo), Wirth \& Blanton, 1956: 98 (male, female; palpalis, contubernalis var. of rozeboomi as syn.; Figs), Forattini, 1957: 248 (in neotropical catalogue; male, female; palpalis, contubernalis var. of rozeboomi as syn.; Figs), Wirth \& Blanton, 1959: 278 (redescript., male, female; palpalis, contubernalis var. of rozeboomi as syn.; Figs), Wirth \& Blanton, 1968: 209 (in key; redescript.; contubernalis var. of rozeboomi as syn.; Figs), Wirth et al., 1988: 20 (in Atlas; wing photo; contubernalis var. of rozeboomi as syn.; distribution), Castellón et al., 1990: 80 (AM, PA records), Borkent $\&$ Wirth, 1997: 85 (in catalogue; contubernalis var. of rozeboomi as syn.), Borkent \& Spinelli, 2000: 35 (in catalogue; contubernalis var. of rozeboomi as syn.), Borkent \& Spinelli, 2007: 69 (in catalogue; contubernalis var. of rozeboomi as syn.), Felippe-Bauer et al., 2008: 260 (in key). 
Diagnosis: species shows the following combination of characters: third palpal segment contains scattered sensilla; mid femur with apical and hind femur with subapical pale band; $r_{3}$ with pale spot present anterior to base of $M_{1}$, a single pale spot crossing second radial cell, apices of $\mathrm{CuA}_{1}$ and $\mathrm{CuA}_{2}$ dark; spermathecae with short, slender necks. Male tergite 9 with a prominent papilliform process on posterior margin; fused portion of the parameres longer than width; separate portion long and V-shaped at base.

Distribution - Mexico to Panama, Brazil (AM, PA). Specimens from Ecuador previously considered to be $C$. verecundus were restored from synonymy by FelippeBauer et al. (2008) and are now known as $C$. contubernalis Ortiz \& Leon.

\section{C. xanifer Wirth \& Blanton}

(Figs 10, 12)

Culicoides xanifer Wirth \& Blanton, 1968: 210 (male, female, Panama; Figs; in key), Wirth et al., 1988: 20 (in Atlas; wing photo; distribution), Borkent \& Wirth, 1997: 85 (in catalogue), Borkent \& Spinelli, 2000: 35 (in catalogue), Borkent \& Spinelli, 2007: 69 (in catalogue), Felippe-Bauer et al., 2008: 260 (in key).

Diagnosis: only species of the hylas group with four or five-branched hyaline sensory filaments on flagellomeres 2-8; third palpal segment with scattered sensilla; mid femur with apical and hind femur with subapical pale band; $r_{3}$ without pale spot anterior to base of $M_{1 ;}$ a single pale spot crosses the second radial cell, apices of $\mathrm{CuA}_{1}$ and $\mathrm{CuA}_{2}$ dark; spermathecae with short, slender necks. Male tergite 9 with a prominent papilliform process on posterior margin; fused portion of the parameres nearly as broad as long, separate portion slender, U-shaped at base.

\section{Distribution - Honduras to Panama.}

\section{ACKNOWLEDGEMENTS}

To Tiago do Nascimento da Silva, for the confection of the figures, and Rodrigo Mexas, for assistance in the wing photographs, to Escola Agrotécnica de São Gabriel da Cachoeira, Ulysses Barbosa and residents, for their assistance in the capture.

\section{REFERENCES}

Aitken THG, Wirth WW, Williams RW, Davies JB, Tikasingh ES 1975. A review of the bloodsucking midges of Trinidad and Tobago, West Indies (Diptera: Ceratopogonidae). J Entomo (B) 44: 101-144.

Barbosa FAS 1947. Culicoides (Diptera: Heleidae) da região neotrópica. An Soc Biol Pernambuco 7: 3-30.

Borkent A, Spinelli GR 2000. Catalog of the new world biting midges south of the United States of America (Diptera: Ceratopogonidae). Contrib Entomol Int 4: 1-107.

Borkent A, Spinelli GR 2007. Neotropical Ceratopogonidae (Diptera: Insecta). In J Adis, JR Arias, G Rueda-Delgado, KM Wnatzen, Aquatic biodiversity in Latin America (ABLA), vol. 4, Pensoft, Sofia-Moscow, p. 1-198.

Borkent A, Wirth WW 1997. World species of biting midges (Diptera: Ceratopogonidae). Bull Am Mus Nat Hist 233: 1-257.

Castellón EG, Ferreira RLM, Silva MNT 1990. Culicoides (Diptera: Ceratopogonidae) na Amazônia Brasileira. I. Coletas na Usina Hidrelétrica (UHE) de Balbina, Usina Hidrelétrica (UHE) Ca- choeira Porteira e Cachoeira dos Espelhos (Rio Xingu). Acta Amazônica 20: 77-81.

Felippe-Bauer ML, Cáceres AG, Silva CS, Valderrama-Bazan W, Gonzales-Perez A, Costa JM 2008. Description of Culicoides pseudoheliconiae sp.n. from Peruvian Amazon and revalidation of Culicoides contubernalis Ortiz \& Leon (Diptera: Ceratopogonidae). Mem Inst Oswaldo Cruz 103: 259-262.

Forattini OP 1957. Culicoides da Região Neotropical (Diptera: Ceratopogonidae). Arq Fac Hig Saude Publ 11: 159-526.

Fox I 1948. Hoffmania, a new subgenus in Culicoides (Diptera: Ceratopogonidae). Proc Biol Soc Wash 61: 21-28.

Fox I, Hoffman WA 1944. New neotropical biting sandflies of the genus Culicoides (Diptera: Ceratopogonidae). Puerto Ric . Publ Hlth Trop Med 20: 108-111.

MacAlpine JF, Peterson BV, Shewell GE, Teskey HJ, Vockeroth JR, Wood DM 1981. Manual of Neartic Diptera, vol. 1, Agriculture Canada, Monograph 27, Otawa, 674 pp.

Macfie JWS 1940. A report on a collection of Ceratopogonidae (Diptera: Ceratopogonidae) from British Guiana. Entomol Monthly Mag 76: 3-32.

Macfie JWS 1948. Some species of Culicoides (Diptera: Ceratopogonidae) from the states of Chiapas, Mexico. Ann Trop Med Parasitol 42: 67-87.

Ortiz I 1950. Estudios en Culicoides. IV. Revision de las especies americanas del subgénero Hoffmania Fox, 1948, con la descripcion de dos nuevas especies. Rev Sanid Asist Soc 15: 437-460.

Ortiz I, Leon LA 1954. Los Culicoides (Diptera: Ceratopogonidae) de la republica del Ecuador. Bol Inf Cient Nac 67: 564-590.

Ortiz I, Mirsa M 1952. Culicoides de Venezuela. Redescripción de 10 especies con la descripción de algunos sexos no conocidos. Rev Sanid Asist Soc 17: 257-279.

Spinelli GR, Ronderos MM, Díaz F, Marino PI 2005. The bloodsucking biting midges of Argentina (Diptera: Ceratopogonidae). Mem Inst Oswaldo Cruz 100: 137-150.

Spinelli GR, Santamaría E, Cabrera OL, Ronderos MM, Suárez MF 2009. Five new species of Culicoides Latreille described from Colombia, yielding a new species list and country records (Diptera: Ceratopogonidae). Mem Inst Oswaldo Cruz 104: 81-92.

Szadziewski R 1996. Biting midges from Lower Cretaceous amber of Lebanon and Upper Cretaceous Siberian amber of Taimyr (Diptera: Ceratopogonidae). Studia Dipterologica 3: 23-86.

Williams RW 1964. Observations on habits of Culicoides larvae in Trinidad, W.I. (Diptera: Ceratopogonidae). Ann Entomol Soc Am 57: 462-466.

Wirth WW, Blanton FS 1956. Studies in Panama Culicoides (Diptera: Heleidae). VI. The hylas group of the subgenus Hoffmania. $J$ Wash Acad Scien 46: 95-99.

Wirth WW, Blanton FS 1959. Biting midges of the genus Culicoides from Panama (Diptera: Heleidae). Proc US Nat Mus 109: 237-482.

Wirth WW, Blanton FS 1968. A revision of the Neotropical biting midges of the hylas group of Culicoides (Diptera: Ceratopogonidae). Fla Entomol 51: 201-215.

Wirth WW, Blanton FS 1973. A review of the maruins or biting midges of the genus Culicoides (Diptera: Ceratopogonidae) in the Amazon Basin. Amazoniana 4: 405-470.

Wirth WW, Dyce AL, Spinelli GR 1988. An Atlas of wing photographs, with summary of the numerical characters of the Neotropical species of Culicoides (Diptera: Ceratopogonidae). Contr Am Entomol Inst 25: 1-72.

Wirth WW, Marston N 1968. A method for mounting small insects on microscope slides in Canada Balsam. Ann Entomol Soc Am 61: 783-784. 